\title{
Merleau-Ponty leitor dos clássicos
}

\author{
Carlos Alberto Ribeiro de Moura \\ calberto@usp.br \\ Universidade de São Paulo, São Paulo, Brasil
}

resumo Este trabalho pretende comentar a doutrina que Merleau-Ponty expõe, em seus distintos períodos, sobre o que caracteriza a obra clássica e sua interpretação. Aponta-se como pressupostos dessa doutrina a admissão de uma certa filosofia da linguagem, bem como de uma particular teoria da produtividade. Em função disso, pergunta-se se, efetivamente, foi feita, ali, uma crítica radical da "filosofia da consciência", como usualmente se supõe.

palavras-chave arte; filosofia; criação; interpretação; linguagem; intencionalidade

Qual seria, para Merleau-Ponty, o verdadeiro ou autêntico "prazer do texto"? Se esta pergunta mimetiza, em sua própria formulação, o título de um livro que Roland Barthes publicou em 1973, é porque soa constante, na filosofia de Merleau-Ponty, apontar para uma convergência plena entre arte e filosofia, ao menos em nosso mundo contemporâneo. Assim, se a "metafísica clássica" podia ser considerada como uma "especialidade" inteiramente divorciada da literatura, para Merleau-Ponty é exatamente isso que muda, quando se abre uma nova "dimensão de pesquisa" que, se na verdade não foi inaugurada pela "filosofia da existência", todavia encontra, nesta, o seu mais forte eco e a sua legitimação oficial. Nesta nova "dimensão de pesquisa", não se trata mais de "explicar" o mundo, através de uma teia de conceitos, nem mesmo de investigar as suas "condições de possibilidade". Agora se reconhece que a vida é metafisica latente, assim 


\section{8}

como a metafísica é explicitação da vida, e o que se torna urgente é formular uma "experiência do mundo", situada aquém de todo sobrevoo conceitual. E se é assim, a filosofia e a literatura têm a mesma tarefa, pois se a "verdadeira filosofia" significa reaprender a ver o mundo, então uma história narrada pode "significar" o mundo tanto quanto um "tratado de filosofia” (MERLEAU-PONTY, 1945, p. XVI). E essa comunidade de objeto e de tarefas levará a uma homogeneidade das técnicas de exposição, a "expressão filosófica" assumindo, doravante, as mesmas "ambiguidades" da "expressão literária” (MERLEAU-PONTY, 1966, p.49).

Se no mundo contemporâneo a arte e a filosofia caminham de mãos dadas, rezando ambas pela mesma cartilha, aquela da volta ao "concreto", é porque, aqui e ali, se redescobre o "mundo percebido". Este mundo percebido é aquele em que vivemos, mas que fomos levados a esquecer, dada a ação deletéria da "filosofia francesa" - ou antes, do "espírito francês" em geral. Porque são estes dois irmãos siameses que o desvalorizam sistematicamente, enquanto "mera aparência", aquilo que apenas encobriria e velaria o "verdadeiro mundo", soletrado sempre e apenas pela ciência (MERLEAU-PONTY, 2002, p.12). E se essa censura não representa qualquer "desmentido" da ciência, é porque se trata, sobretudo, de perguntar se esta nos fornece uma "representação tão completa do mundo", que não daria mais lugar a nenhuma questão válida, ao lado de sua tópica própria, sempre restrita às leis, ao cálculo e à mensuração. Mais ainda, é a própria ciência contemporânea, liberta dos mitos da ciência clássica, que nos convida a esta reabilitação do mundo percebido, ao reconhecer-se como sempre aproximativa. Afinal, o "concreto" não pode ser deduzido das leis, ao contrário, a lei é sua expressão aproximativa, o que deixa sempre subsistir uma opacidade. E se doravante o "concreto" convida a ciência a uma elucidação interminável, ele não pode mais ser considerado, ao modo clássico, como uma "aparência" a ser sempre "ultrapassada" (MERLEAU-PONTY, 2002, p.15).

Vem daí o elo estreito entre uma "filosofia da percepção", que se dedica a reaprender a ver aquele "mundo", sempre recalcado pelo "espírito francês", e a arte em geral, ou a pintura, em particular, que nos reconduz à visão da "coisa mesma" (MERLEAU-PONTY, 2002, p. 53). Tanto na percepção quanto na arte, a definição e a análise não substituem a experiência direta. Tanto no poema quanto na coisa percebida, não se pode 
separar o fundo e a forma, o que é apresentado e a maneira pela qual aquilo se apresenta. E por isso mesmo o romance bem sucedido não existe como soma de ideias ou de teses, mas sim como uma "coisa sensível", que se trata de perceber nos seus detalhes. Assim como na literatura, tanto na percepção quanto na pintura é impossível separar a coisa de suas maneiras de aparecer (MERLEAU-PONTY, 2002, p. 56). Por isso, nenhuma surpresa se Cézanne, lido por Merleau-Ponty, fosse apresentado por ele como sendo o retratista, por excelência, do horizonte da "préobjetividade", tal como este era descrito na Fenomenologia da percepção. Afinal, Cézanne não separava as "coisas" de suas "maneiras de aparecer" e, por isso mesmo, ao seu modo, ele já retraçava a genealogia do "objetivo" a partir do "pré-objetivo", do "determinado" a partir de sua fonte no "indeterminado positivo", ele se dedicava a pintar "a vibração das aparências que é o berço das coisas” (MERLEAU-PONTY, 1966, p. 30). Em suma, Cézanne já "pintava" a mesma etiologia que a Fenomenologia da percepção nos "narrava”.

E sabe-se que esta convergência entre arte e filosofia não é, de forma alguma, uma obsessão exclusiva do "jovem” Merleau-Ponty, atrelada à sua "filosofia da existência”. Ao contrário, ela permanecerá reafirmada em $O$ visível e o invisível. Afinal, ali se dirá que a filosofia "faz ver por palavras", e que ela faz isso simplesmente "como toda a literatura" (MERLEAUPONTY, 1964, p. 319). Se o sensível e a vida não inspiram nada a quem não é escritor, eles são plenos de coisas a se dizer para "aquele que é filósofo", - quer dizer, "escritor". E, por isso, a "filosofia do sensível" poderá ser apresentada como "literatura" (MERLEAU-PONTY, 1964, p. 305).E Merleau-Ponty não deixará de indicar que uma de suas metas, neste seu último período, era precisamente retomar e aprofundar a visão de Souriau, aquela que considerava a filosofia como sendo nada mais, nada menos, do que a "arte suprema" (MERLEAU-PONTY, 1964, p. 251).

Isso significaria que o prazer merleau-pontyano do texto seria um "prazer estético", no sentido usual ou corriqueiro da palavra? As suas páginas indicam, de forma bem barulhenta, que se trata exatamente do contrário. Afinal, mesmo nos ensaios em que comenta exclusivamente as obras de arte, e não de filosofia, Merleau-Ponty não deixará de exprimir sua exasperação diante dos temas usuais da estética, a ponto de relembrar um texto em que Heidegger censurava uma certa estética, por situar, 
abusivamente, a obra de arte nos domínios do "confeiteiro". Assim, quando analisa a pintura de Cézanne, Merleau-Ponty faz questão de sublinhar que sua obra não é qualquer "fabricação" orientada pelos "desejos do bom gosto" (MERLEAU-PONTY, 1966, p 30). Uma tese que, no final das contas, devemos simplesmente generalizar, reconhecendo que nem mesmo existe "arte de agrado" (MERLEAU-PONTY, 1966, p. 32). Essa obsessão permanecerá no "período intermediário" da filosofia de Merleau-Ponty, com o reconhecimento de que o "insubstituível" na obra de arte é aquilo que faz dela "muito mais que um meio de prazer: um órgão do espírito” (MERLEAU-PONTY, 1960, p. 96). E o último texto que Merleau-Ponty publica em vida, O olho e o espírito, discorrerá longamente sobre a pintura, sem enunciar, em momento algum, qualquer "juízo de gosto".

Nos textos de seu primeiro período, o essencial da arte, assim como da filosofia, estará na criação de um sentido absolutamente inédito. Tese que sofrerá uma certa inflexão, no período intermediário. Assim, se Balzac e Cézanne são mais que "animais cultivados", é precisamente pelo reconhecimento de que o fundamental na arte é a criação de um sentido inteiramente novo, e não propiciar qualquer "prazer estético". Afinal, sempre se pode fabricar "objetos que dão prazer", simplesmente "ligando de outra maneira ideias já prontas e apresentando formas já vistas" (MERLEAU-PONTY, 1966, p. 32). A verdadeira arte é "expressão", coisa que ninguém deve confundir com a mera "tradução" de um pensamento já dado. Assim, se exprimir é criar, e se a criação não se dá sem "situação" e sem "motivação", resta que "o sentido daquilo que o artista vai dizer não está em parte alguma, nem nas coisas, que ainda não são sentido, nem nele mesmo, em sua vida não formulada" (MERLEAUPONTY, 1966, p. 32). Assim, no primeiro período de sua filosofia, para Merleu-Ponty expressão é esta operação difícil e "genial", no sentido kantiano da palavra, em que, por princípio, a "concepção" não pode preceder a "execução". E é nessa mesma linha que a Fenomenologia da percepção oporá a "fala autêntica", aquela que formula "pela primeira vez", a uma "expressão segunda", que constitui o uso comum de nossa "linguagem empírica" (MERLEAU-PONTY, 1945, p. 207). O "verdadeiro autor", partilhando com seu leitor a mesma linguagem instituída, insensivelmente desvia os signos de seu sentido comum, e empurra 
o leitor para um outro sentido, que este terminará por alcançar. O livro é um "aparelho para criar significações", a linguagem "falante" é a "operação" pela qual um certo arranjo dos signos e significações disponíveis secreta uma "significação nova" (MERLEAU-PONTY, 1969, p. 19/20). Assim, o prazer merleau-pontyano do texto é sempre aquele trazido pelo contato com um "sentido inédito".

Isso excluirá liminarmente, do comentário merleau-pontyano da arte ou da filosofia, categorias como "imitação" ou "semelhança". Se o quadro representa objetos, ou até mesmo pessoas que têm nomes, sua função não é, de forma alguma, nos dirigir a algo de exterior. Isso seria supor que a significação da pintura está fora dela, em coisas para as quais ela apontaria. Mas não é este o trabalho da "pintura válida", como aquela de Cézanne, que longe de ser "imitação" do mundo, é sempre um mundo "para si" (MERLEAU-PONTY, 2002, p. 56). Na experiência do quadro, não há reenvio a algo de exterior, ou "semelhança" em relação a algum modelo. O espetáculo presente na tela é algo que "se basta". E o mesmo vale para a literatura, desde que saibamos distinguir, com Mallarmé, o uso poético da língua, da tagarelice quotidiana. Se o tagarela apenas "nomeia" coisas no uso empírico da linguagem, a fala poética é inteiramente guiada pela própria linguagem, "sem referência direta ao próprio mundo, nem à verdade prosaica” (MERLEAU-PONTY, 2002, p. 60). E tem todo cabimento estender ao romance e à literatura em geral, o que Mallarmé dizia da poesia. E é exatamente isso que Merleau-Ponty estenderá, também, à própria filosofia. Afinal, neste momento, só podia ser de bom tom proclamar, em alto e bom som, que "a filosofia não é o reflexo de uma verdade prévia mas, assim como a arte, a realização de uma verdade" (MERLEAU-PONTY, 1945, p. XV).

Nos textos de seu primeiro período, esta criatividade era comentada por Merleau-Ponty, seguindo fielmente as lições de Goldstein, como sendo uma produtividade do homem (MERLEAU-PONTY, 1945, p. 229). Mas resta que, nesse momento, a palavra "homem" só podia ser compreendida, por Merleau-Ponty, no interior de uma certa "filosofia da consciência”. E isso não era, de forma alguma, sem consequências. Assim, quando se procurava descrever a "intenção significativa em estado nascente", esta tarefa não se fazia sem instalar uma oposição entre natureza e cultura. Afinal, Merleau-Ponty descreverá este momento da 
"criação" como sendo aquele em que a "existência" se polariza em um certo sentido "que não pode ser definido por nenhum ser natural". E a "fala autêntica" ou criadora será compreendida, neste momento, como sendo "o excesso de nossa existência em face do ser natural" (MERLEAU-PONTY, 1945, p. 229). E sabe-se que esta "existência” será pura e simplesmente identificada ao "cogito tácito". Por trás da palavra "homem", é o cogito tácito que sempre "se transcende em direção a um comportamento novo..., ou em direção ao seu próprio pensamento por meio de seu corpo e de sua fala" (MERLEAU-PONTY, 1945, pp. 462/ 226) É uma "consciência" a soberana detentora daquela "produtividade" ou "potência aberta e indefinida de significar", o polo de onde se irradia um "sentido inédito", que posteriormente se sedimentará na cultura. E Merleau-Ponty não deixará de indicar que essa "produtividade" deve ser vista por nós como um "fato último", pois qualquer "explicação" resultaria em negá-la, "seja a explicação empirista, que reconduz as significações novas às significações dadas, seja a explicação idealista, que põe um saber absoluto imanente às primeiras formas do saber" (MERLEAUPONTY, 1945. p. 447). Nessas circunstâncias, como não haveria uma "dúvida de Cézanne"? Se a criação tem sua fonte exclusiva em um cogito insular, como não suspeitar, a cada momento, tanto da "validade" da obra, para o seu próprio criador, hoje e amanhã, quanto da sua comunicabilidade às outras "consciências"?

Nos textos do período intermediário de Merleau-Ponty, a vida do pintor ou do escritor já não será mais tão dura. E isso porque, ali, já se prepara a "reabilitação ontológica do sensível", a inscrição plena do inteligível no sensível. Uma vez neutralizado o poder imperial da "consciência", não se dirá mais que o sentido daquilo que o artista vai dizer não está em parte alguma. Se permanece verdadeiro que a pintura nunca é "representação", mas sim expressão criadora, resta que, doravante, o pintor "concentra", na tela, um sentido difuso no que ele vê, o estilo germina na superficie de sua experiência, onde "um sentido operante e latente" encontra os emblemas que o libertam e o tornam "manejável pelo artista, ao mesmo tempo que acessível aos outros" (MERLEAU-PONTY, 1960, p 66). Da mesma forma, se o escritor faz um uso criador da linguagem, a fala autêntica apenas libera um sentido cativo nas coisas, a "grande prosa" não é senão "a arte de captar um sentido que jamais tinha 
sido objetivado até então, e de torna-lo acessível a todos os que falam a mesma língua" (MERLEAU-PONTY, 2000, p. 45). Assim, se a obra literária é certamente criada, resta que essa criação não se faz mais ex nihilo, mas sim a partir daquilo que o escritor "vê" (MERLEAU-PONTY, 1996, p. 217). E, por isso mesmo, entrará em eclipse a ideia de um "milagre da expressão", tão presente na Fenomenologia da percepção. Assim, se doravante a criação artística é sempre metamorfose de um sentido cativo nas coisas, ela não o é no sentido dos "contos de fadas", "milagre", "magia", "criação absoluta" em uma "solidão" que, agora, Merleau-Ponty considerará "agressiva”, e que era, certamente, a solidão de seu antigo Cézanne. Agora, longe de celebrar qualquer solidão ontológica, a "metamorfose" do sentido "cativo" nas coisas será sociabilidade originária, resposta "àquilo que o mundo, o passado, as obras feitas pediam" (MERLEAU-PONTY, 1960, p. 73).Assim, doravante todas as artes devem ser vistas como leituras criativas do mundo. E se antes a filosofia era a "realização de uma verdade", o contrário mesmo de qualquer "reflexo de uma verdade prévia”, a partir de agora ela se tornará aquela "discreta leitura” do mundo, que Foucault expressamente censurará: sua tarefa será traduzir o "simbolismo tácito da vida" em um "simbolismo consciente", seu papel será aquele de gestora da passagem do "sentido latente" ao “sentido manifesto" (MERLEAU-PONTY, 1989, p. 58).

Por isso, é claro que, no interior deste novo cenário, não haverá mais lugar algum para qualquer "dúvida de Cézanne". Muito pelo contrário. O Cézanne comentado por Merleau-Ponty no seu primeiro período, ainda era alguém visado através das lentes de uma filosofia da "má ambiguidade", aquela que se comprazia com uma pura "mistura da finitude e da universalidade, da interioridade e da exterioridade" (MERLEAU-PONTY, 2000, p.48). Doravante, aquela "dúvida” arcaica de Cézanne cederá seu estrelato a uma "convicção" nova e bem firme, como aquela de Stendhal, com a sua certeza de que seria lido "em cem anos” (MERLEAU-PONTY, 1960, p. 93). Afinal, no interior desta nova interpretação, o público ao qual a arte se dirige, antes de ser antecipadamente dado, é suscitado pela própria obra. O artista mais forma o seu público do que o segue, ele lhe propõe valores que apenas a seguir este público reconhecerá como seus valores. Mais ainda, se há um julgamento da obra, ele se confunde com o diálogo perpétuo entre todas as falas, e a 
antiga dúvida será substituída pela "certeza interior de ter dito aquilo que, nas coisas, esperava ser dito, e que, portanto, não poderia deixar de ser entendido por X... (MERLEAU-PONTY, 1960, pp. 92/3). E se expressão caminha de homem a homem através do mundo comum que eles vivem, então será preciso reconhecer que, em regime de "boa ambiguidade", ninguém precisa escolher entre o para si e o para outrem, visto que, no "momento da expressão", o autor e seu publico estão "ligados sem concessão" (MERLEAU-PONTY, 1960, p. 92). Se aquilo que o escritor diz não pré existe à sua obra, todavia não há mais qualquer dificuldade em compreender como pode haver criação de um sentido novo e, ao mesmo tempo, sua compreensão por outrem. Afinal, o mundo que o escritor diz é o mundo visível, sensível e mudo, "ao qual estamos todos abertos" (MERLEAU-PONTY, 1996, p. 203).

Mas é certo também que esta celebração eufórica do "sentido inédito", em qualquer uma de suas variantes, seja em sua criação "absoluta", nos textos do primeiro período, seja na sua "metamorfose criadora" de um sentido "latente" na experiência, ali na fase "intermediária", ainda não permite, por si só, que se possa discernir entre o autor "clássico" e o "não clássico”. Se essa distinção, trivialmente necessária, é só levemente sugerida nos textos da primeira fase, ela será explicitada por Merleau-Ponty em seu período intermediário. Agora se dirá que aquilo que faz da obra de arte um "órgão do espírito", que tem seu análogo em todo pensamento filosófico ou político, desde que este seja "produtivo", é conter, "melhor que ideias, matrizes de ideias", cujo "sentido" nós nunca terminaremos de desdobrar (MERLEAU-PONTY, 1960, pp. 96/7). A obra clássica é aquela que se presta a um comentário infinito. Em suas corriqueiras analogias de tudo com a decodificação fenomenológica de nossa vida perceptiva, Merleau-Ponty dirá que o "grande livro" é "tão singular e inesgotável quanto a coisa vista” (MERLEAU-PONTY, 1969, p. 16). E se é assim, apenas a obra clássica pode ser caracterizada como uma instituição. Se a instituição é "matriz simbólica", que faz com que haja abertura de um campo, de um porvir, é porque ela é o estabelecimento, em uma experiência, de dimensões em relação às quais toda uma série de outras experiências terão sentido, ela inaugura uma história (MERLEAUPONTY, 2003. p. 38). Por isso, se a "significação total" de um livro só existe "no infinito, como soma dos encontros de outros espíritos com a 
obra", resta que este "sentido externo" só existe graças a um "sentido interno" à obra, que é sempre "aberto" (MERELAU-PONTY, 2003, p. 41). Desde então, se Goethe dizia que o gênio é "produtividade póstuma”, na tradução proposta por Merleau-Ponty nós deveremos afirmar que toda instituição é "gênio" (MERLEAU-PONTY, 2003, p. 38).

À primeira vista, esta tese de Merleau-Ponty parece apenas reeditar um lugar comum bastante trivial, por todos nós bem conhecido. Afinal, quando Ítalo Calvino se perguntava o que é um clássico, sua resposta ia exatamente nesta direção: a obra clássica é aquela que faculta inúmeras leituras. E desde os anos 1950, Umberto Eco apresentava como característica mais marcante da nova arte querer compreender-se sempre como "obra aberta", aquela que deixa a critério exclusivo de seu distinto público as suas inevitavelmente múltiplas "interpretações”. Mais ainda, quando Walter Benjamin se referia à "aura" da obra de arte, ele sinalizava com isso a evidência que a obra de arte é um "produto", mas tão "enigmático", que nenhuma inspeção de seu consumidor seria capaz de esgotar a sua significação. E se quisermos recuar para bem mais longe no tempo, ali no $\int 49$ da Crítica da faculdade de julgar, Kant apresentava a "ideia estética" como uma representação que "dá muito a pensar", mas sem que qualquer pensamento determinado, qualquer conceito, lhe seja adequado. Assim, a ideia estética nos conduz a vários pensamentos determinados, sem que qualquer um deles a exprima adequadamente. Por isso, Kant dirá que nenhuma língua pode exprimir completamente uma ideia estética, e torná-la inteligível. Mas então, será que Merleau-Ponty apenas reataria com este ideário, há muito tempo enraizado, e por isso mesmo bastante difuso? Digamos, na contracorrente, que o "específico" de sua compreensão da obra "clássica" só se revela quando situamos a sua tese no interior do cenário filosófico em que ela se instala, e que lhe dá, aliás, seu fundamento. E esse cenário envolve uma determinada filosofia da linguagem, bem como uma particular filosofia da "produtividade".

\section{II}

Esta compreensão de Merleau-Ponty sobre o que é um clássico é indissociável, em primeiro lugar, de sua tese segundo a qual toda linguagem 
criadora é "indireta ou alusiva". Se o escritor fosse, invariavelmente, um bem sucedido prosador sartriano, - este personagem sempre siderado pelas significações "diretas", - nem haveria lugar para múltiplas interpretações de uma obra. Afinal, se ao contrário do poeta, que transforma as palavras em "coisas", o prosador ao gosto de Sartre é alguém que lida com significados, ele tem na sua linguagem um instrumento para a busca da verdade. Se a prosa é essencialmente utilitária e o prosador se serve das palavras, aqui a linguagem se presta a um uso bem definido. "A arte da prosa se exerce sobre o discurso, sua matéria é naturalmente significante: vale dizer, as palavras não são, de início, objetos, mas designações de objetos" (SARTRE, 1989, p. 18). Se a linguagem do prosador é essencialmente designativa, então se deve dar razão a Valéry: existe prosa quando nosso olhar atravessa a palavra como o sol ao vidro. E por isso, garante Sartre, frequentemente estamos em posse de uma ideia, que nos foi comunicada por palavras, sem que nos lembremos de nenhuma delas. E se é assim, na prosa bem sucedida a própria linguagem deve se apagar, ou se fazer esquecer, ao colocar o seu feliz leitor em contato direto com a coisa mesma.

Este prosador sartriano era, por isso, apenas um usuário a mais daquilo que Merleau-Ponty chamava de "fantasma de uma linguagem pura". Essa "linguagem pura" era aquela sempre cativa da "concepção clássica da expressão”, invariavelmente compreendida como uma pura relação de "denotação" entre signos e significações (MERLEAU-PONTY, 1969, p, 40). Essa linguagem "direta", que se faz esquecer em benefício da "coisa mesma", trata a literatura como mera variante do "enunciado", suposta "forma pura de expressão", que associa signos a acontecimentos ou a ideias, e nos faz simplesmente escorregar do signo para o objeto que ele designa. Sabe-se qual será a objeção de fundo que Merleau-Ponty dirigirá a essa "concepção clássica" da expressão: se este trivial simples ainda pode comentar a nossa linguagem instituída ou "empírica", resta que ele é incapaz de dar conta da linguagem criadora ou "transcendental". Aquela "expressão pura" será sempre une jeune fille rangée, visto que ela "só contém aquilo que mostra" (MERLEAU-PONTY, 1969, p. 7). Se a fala é puro signo para uma pura significação, então "não há virtude da fala, nenhum poder nela escondido" (MERLEAU-PONTY, 1969, p. 12).

É justamente este "poder escondido" da fala criadora que MerleauPonty pretende resgatar, através de sua muito particular apropriação das 
teses de Saussure. O que terá por resultado final, como se sabe, uma compreensão não mais instrumentalista ou sartriana da linguagem. Longe de entrar na sua nova cena como simples "meio" para um fim que lhe é exterior, mera tradução de um texto ideal pré-dado, a linguagem será interpretada, doravante, como uma espécie de "ser" (MERELEAUPONTY, 1960, p. 54). Ela terá, portanto, uma vida própria, e por isso mesmo nunca se reduzirá à pura "denotação" de uma significação que lhe seria prévia. Afinal, a lição a se extrair de Saussure é a de que os signos nada exprimem quando tomados um a um, isoladamente, mas apenas em seu jogo com os demais signos. Se os signos são diacríticos, se eles só dizem alguma coisa enquanto se "perfilam" sobre os outros signos, então o "sentido" é a maneira pela qual um signo se comporta em relação aos outros signos, é a relação lateral de signo a signo que funda a relação final do signo ao sentido (MERLEAU-PONTY, 1960, p. 51). E se essa linguagem criadora é assim sempre indireta ou alusiva, o sentido não pode ser destacado da própria linguagem, e esta não pode se fazer "apagar" ou "esquecer", em benefício de um suposto "sentido puro". Ao contrario do que ocorria em regime de "expressão pura", a linguagem indireta, longe de ser um mero índice para significações prontas, é aquilo que faz "existir" as significações (MERLEAU-PONTY, 1960, p. 53). E se é assim, nenhuma linguagem se perfaz para fazer aparecer a "coisa mesma", visto que "o sentido está implicado pelo edifício das palavras, antes que designado por elas" (MERLEAU-PONTY, 1960, p, 103). E se a "coisa mesma”, a "significação sem signo", não passa de pura ilusão, nós deveremos abandonar também os outros mitos conjugados àquele da expressão pura, bem como extrair as consequências desta nova interpretação.

Assim, se nossa linguagem nunca é "denotativa”, se não podemos nem mesmo "sonhar" com uma linguagem que nos dê acesso a "significações nuas", se os signos tomados um a um não têm poder significante que se possa isolar, se o próprio "sentido" não é nada de prévio à linguagem, mas só existe graças ao seu trabalho, então será preciso renunciar ao léxico clássico da "adequação" entre um representante e um representado, visto que não há significação prévia à linguagem à qual esta deveria se "adequar". Desde então, se deve reconhecer que não há expressão "absoluta" ou "consumada", assim como nenhuma comunicação poderá ser "integral" ou definitiva (MERLEAU-PONTY, 1969, p. 42). Por isso, se o prosador 
segundo Merleau-Ponty também se ocupa com a "verdade", assim como o seu homônimo sartriano, ele saberá, contudo, que sua linguagem apenas "faz transparecer o verdadeiro, mas não o toca". E se é assim, se a linguagem nunca cessa para dar lugar a um "sentido puro", existirá sempre uma "opacidade" da linguagem, sancionada por sua perpétua "referência a si mesma” (MERLEAU-PONTY, 1960, pp. 98/ 54).

Mas para Merleau-Ponty esta opacidade, longe de representar um obstáculo a ser "ultrapassado" por alguma ação "purificadora" sobre a nossa linguagem, é justamente o que faz desta linguagem um "poder espiritual", algo que "dá a pensar", que sempre pode "inaugurar uma discussão", ao invés de monotonamente "reproduzir" coisas. Assim sendo, é apenas quando concebemos a linguagem como indireta que se pode compreender porque uma obra clássica contém, antes que ideias, matrizes de ideias, que nunca terminaremos de desdobrar. E por isso o prosador ao gosto de Merleau-Ponty estará bem distante daquele outro, que tinha seu rosto rascunhado por Sartre. Ao menos, ele sempre saberá que são apenas "homônimos" entre si o romance "como resenha de acontecimentos, como enunciado de ideias, teses ou conclusões, como significação manifesta ou prosaica, e o romance como operação de um estilo, significação oblíqua ou latente" (MERLEAU-PONTY, 1960, p. 96).

É esta doutrina da linguagem indireta que estará subjacente às teses do Merleau-Ponty leitor ou historiador dos clássicos da filosofia. Se o livro "válido" é aquele que se ultrapassa enquanto acontecimento datado, é porque ele tem sentido fora de seu contexto histórico. Mais ainda, “ele só tem sentido fora desse contexto" (MERLEAU-PONTY, 1964. p. 253). Se esta filosofia é fala falante, não fala falada, é porque a prosa da filosofia também não será tecida por qualquer linguagem direta. Ao contrário, para Merleau-Ponty a filosofia "é inseparável da expressão literária, da expressão indireta (MERLEAU-PONTY, 1996, p. 391). Essa aproximação final entre arte e filosofia trará o benefício que se conhece: se a prosa filosófica é, ela também, expressão indireta, será preciso reconhecer que "uma filosofia, assim como uma obra de arte, é um objeto que pode suscitar mais pensamentos que aqueles ali contidos" (MERLEAUPONTY, 1964. p. 253). Mas essa tese, justamente, suscita uma questão preliminar, que dará início ao severo processo de Merleau-Ponty contra a história “objetiva” da filosofia, que terá em Gueroult o seu alvo principal: 
será que podemos, efetivamente, recensear os pensamentos realmente "contidos" em uma filosofia?

Em história da filosofia, será que estaríamos invariavelmente condenados à alternativa entre, por um lado, deformar a obra ou, por outro, reproduzi-la literalmente? Seríamos sempre ou verídicos ou falsificadores? Para Merleau-Ponty, quem acredita nessa alternativa pensa que o filósofo é sempre um prosador sartriano a mais e, por isso, quer "que a significação de uma obra seja inteiramente positiva e suscetível, de direito, a um inventário que delimite aquilo que ali está e aquilo que ali não está" (MERLEAU-PONTY,1960, p. 202). Mas essa pretensão seria, ao menos, minimamente sensata? Existem razões de sobra para se duvidar. Em regime de linguagem indireta, será preciso reconhecer que "a filosofia, assim como a arte, não cerca seu objeto, não o tem em mãos de maneira que não deixe nada a desejar" (MERLEAU-PONTY, 1969, p. 129). Assim, nenhuma surpresa se, na estante de Merleau-Ponty, Sartre e Gueroult estiverem situados na mesma prateleira. Contra Sartre, vale a pena relembrar que nenhuma fronteira indica até onde vai Descartes, e em que ponto começam seus sucessores. Por isso, tem tanto cabimento enumerar os pensamentos que estão em Descartes, e aqueles que estão em seus sucessores, quanto fazer o inventário de uma língua (MERLEAUPONTY, 1989, p. 146). Gueroult e Sartre rezam pela mesma cartilha, e é isso que fica claro para quem avalia o sentido das "metamorfoses" do pensamento de Descartes.

Por um lado, é bem certo que Espinosa, Malebranche e Leibniz reivindicam, cada um deles, o seu Descartes e, à sua maneira, distribuem diferentemente os acentos, bem como mudam a relação entre figura e fundo na obra de Descartes (MERLEAU-PONTY, 1969, p. 129). Mas será que devemos falar, ao estilo da história “objetiva”, que cada um deles, ao seu modo, "falsifica" Descartes? É preferível reconhecer que, em regime de linguagem indireta, a oposição entre o verdadeiro e o falso não é tão pertinente para a avaliação de conjunto de uma interpretação. Afinal, "o pensamento do filósofo, - o mais decidido que este seja a ser explícito, a se definir, a se distinguir - assim como a pensamento alusivo do romancista, não exprime sem subentendido" (MERLEAU-PONTY, 1969, p. 137). Desde então, se Descartes é Descartes, ele é também tudo aquilo que o anunciava e tudo aquilo que derivou dele, "como o 
ocasionalismo de Malebranche, escondido em um canto da Dióptrica (MERELAU-PONTY, 1969, p. 130). Nessas circunstancias, teria cabimento traçar o limite entre aquilo que Descartes pensou e aquilo que se pensou a partir dele? Vem daí a comparação que Merleau-Ponty fará entre o "campo do espírito" e o "campo visual": assim como este, aquele também não é limitado por qualquer fronteira nítida, mas se perde em uma zona vaga, em que a alternativa entre a presença plena e a pura ausência não tem mais lugar (MERELAU-PONTY, 1969, p. 131).

Mas se isso aponta apenas para uma mera "analogia" entre ver e ler, sempre contestável, como qualquer analogia, resta que Merleau-ponty formulará ainda uma "razão de princípio" para que se proíba, liminarmente, o inventário dos pensamentos que estariam " realmente contidos" em alguma filosofia. A saber, o pensamento de um filósofo não é uma "soma de ideias", mas antes, "um movimento que deixa atrás de si seu rastro e antecipa seu porvir" (MERLEAU-PONTY, 1969, p. 132). Se ao invés de ser "positiva”, a significação da obra é "aberta”, essa significação como que solicita a sua própria "metamorfose", e é em vão que se procurará algum pensamento que só pertenceria a Descartes. Por isso, se em regime de linguagem indireta o "fechamento" de um pensamento é impossível, a questão de se saber a quem um pensamento "pertence", no limite, não pode ter qualquer sentido. (MERLEAU-PONTY, 1969, p. 133). E por isso terá todo cabimento propor, ao lado da história da filosofia à la Gueroult, uma "história do subentendido", em que a linguagem filosófica não será mais considerada como soma de enunciados e de soluções (MERELAU-PONTY, 1964, p. 252).

Mas esta própria "história do subentendido" suscita uma certa suspeita, aquela relativa ao Gueroult que posa, pomposamente, diante de seu distinto público, como o campeão máximo da "objetividade" em história da filosofia. Que sentido pode ter esta "objetividade" se, em regime de linguagem indireta, a "adequação" é apenas sinalizada, mas nunca efetivamente alcançada? (MERLEAU-PONTY, 1996, p. 391). E se é da "natureza mesma" da expressão o fato de que ali não se pode enumerar o que é dito e o que é subentendido, então toda interpretação de uma filosofia envolve uma escolha "subjetiva". A própria interpretação de Descartes por Gueroult envolve uma perspectiva "subjetiva". E para Merleau-Ponty o "subjetivo", ali, já está exatamente na pressuposição de 
que toda filosofia é feita de "problemas", que ela é criação e solução de problemas (MERLEAU-PONTY, 1964, p. 241). Afirmar que a filosofia gira em torno de "problemas", que ela se resume a determinar incógnitas a partir de termos conhecidos, não é efetivamente uma escolha subjetiva? Afinal, se nas Regulae Descartes define assim as suas questões, resta que estas não recobrem a totalidade de sua filosofia (MERLEAU-PONTY, 1996, p. 221). E sabe-se que Merleau-Ponty recusará, expressamente, a pertinência da noção de "problema" para comentar a sua própria filosofia.

Isso significaria reconhecer que, em história da filosofia, estaríamos condenados, de antemão, seja a uma história que se quer objetiva, e que por isso mesmo é "insignificante" (MERLEAU-PONTY, 1964, p. 239), seja ao puro e simples carnaval da subjetividade, ao relativismo e ao ceticismo? Não se trata disso. Trata-se, sobretudo, de indicar que não estamos obrigados a escolher entre Gueroult ou Hegel. O que Merleau-Ponty procura é definir uma história da filosofia que não seja nem o aplainamento da história em uma filosofia, mas que também não seja "idolatria", retomada ou "repetição de Descartes" (MERELAU-PONTY, 1964, p. 251). Mas como obter este difícil equilíbrio, um meio termo nunca previsto por qualquer dos membros de nossas escolas ou escolhas rivais? Trata-se de encontrar um terceiro caminho que escape ao dilema que se formula a partir da pergunta feita por Gouhier: pode-se colocar a uma filosofia questões que ela não se colocou? "Responder não, é fazer delas obras separadas, é negar a filosofia. Responder sim, é reduzir a história à filosofia" (MERLEAU-PONTY, 1964, p. 252/3). Merleau-Ponty historiador de Husserl será o bom exemplo da tentativa de se percorrer uma terceira via, que escape daquela disjunção.

Afinal, pode-se muito bem ler Husserl, mantendo a profilática equidistância daqueles vícios simétricos e inversos, a saber, sem mutilá-lo "avaramente" do que ele deu a pensar aos outros, como faz a história "objetiva", mas também sem fazer dessa leitura uma deformação arbitrária. Para tanto, basta começar por reconhecer a existência de um "impensado" de Husserl, algo que, por um lado, "é dele", mas que, por outro lado, "dá acesso a outra coisa” (MERLEAU-PONTY, 1960, p. 202). Mas para empreender esta tarefa, é preciso começar por circunscrever um certo plano em que se situa esta leitura "vertical" ou "filosofante" da história da filosofia. E isso se faz diferenciando, na obra, entre os "objetos de pensamento" ou as "coisas 
ditas", por um lado, e as "articulações" entre as coisas ditas, por outro. Como sempre em Merleau-Ponty, vale a analogia entre a obra e a vida perceptiva. Assim como as coisas percebidas têm seus horizontes, "que não são coisas e que não são nada", as obras de pensamento são feitas também de "certas articulações entre as coisas ditas". Mas essas "articulações" não são objetos de pensamento e por isso, nesse plano, "não há dilema da interpretação objetiva e do arbitrário" (MERELAU-PONTY, 1960, p. 202). Assim como o horizonte do percebido não subsiste isoladamente, a obra não deve ser submetida ao "pensamento isolante", e só seremos fiéis às suas "articulações" pensando-as novamente. Por isso, se existe uma "verdade de Descartes", é "sob a condição de que a leiamos entre as linhas" (MERLEAU-PONTY, 1964, p. 242). Se "pensar" é equivalente a circunscrever um horizonte, então pensar "não é possuir objetos de pensamento, é circunscrever, por eles, um domínio a pensar, que portanto não pensamos ainda" (MERLEAU-PONTY, 1960, p. 202). Correlativamente, "compreender" a obra será explorar o horizonte que ela abre, será "apreender por coexistência, lateralmente, por estilo, e através disso alcançar, de um só golpe, os longínquos desse estilo e deste aparelho cultural" (MERLEAU-PONTY, 1964, p. 242).

Mas é claro, também, que esta história "vertical" da filosofia não se sustenta sem a arcaica postulação de uma philosophia perennis. Assim, podese repetir, à exaustão, que nessa história não se reduz as filosofias a uma filosofia, a um plano único, mas que, ao contrário, se reconhece nelas um “escalonamento em profundidade" (MERLEAU-PONTY, 1964, p. 239). Mas se a única maneira de restituir a Descartes a sua verdade é pensá-la novamente, "quer dizer, a partir de nós" (MERELAU-PONTY, 1964, p. 251), o historiador "vertical" precisará distinguir, ao menos idealmente, entre os problemas de Descartes e Malebranche, "tais como eles os pensam", e os problemas "que os movem verdadeiramente". Mas esses problemas que os movem verdadeiramente, são aqueles "que nós formulamos" (MERLEAU-PONTY, 1964, p. 253). Assim, este historiador conhece Descartes e Malebranche bem melhor do que estes conheceram a si mesmos, seu olhar privilegiado é o único a circunscrever os problemas que os movem "verdadeiramente". E se Merleau-Ponty historiador afirma que, na prática, nem é necessário fazer essa distinção entre os problemas "deles" e aqueles que "nós formulamos", é porque parte-se da 
convicção de que a "projeção" de um pensamento no outro sempre deixa transparecer um mesmo "núcleo de ser". O escalonamento em "profundidade" das filosofias não pró́be que elas reenviem umas às outras, visto que, aqui como ali, "trata-se do mesmo Ser" (MERLEAU-PONTY, 1964, p. 239).

Por isso, se Gueroult recomenda que sigamos os filósofos em seus problemas, resta que "seus problemas são interiores àquele do Ser: isso, eles o professam todos, e portanto nós podemos, nós devemos, pensá-los nesse horizonte" (MERELAU-PONTY, 1964, p. 251). Assim, se a história "vertical" não impõe a Descartes um ponto de vista exterior à sua filosofia, uma questão que não seria sua, é porque se supõe, singelamente, poder mostrar que "há um absoluto, uma filosofia, que é imanente à história da filosofia” (MERLEAU-PONTY, 1964, p. 242). E se é assim, todas as filosofias clássicas estarão, doravante, em regime de "eternidade existencial", e a história vertical, que as lê e interpreta, não pode inspirar qualquer relativismo, visto que o "pensamento interrogativo", que faz cada filosofia "falar", não é nem pode ser "ultrapassado" pelo que virá depois (MERLEAU-PONTY, 1964, p. 253). Afinal, os diferentes balbucios do Ser ecoam, sempre, o mesmo "Ser". Por isso, se a "história objetiva” de Gueroult é criticável por ser "racionalismo dogmático”, por ser "uma filosofia", e não aquilo que ela pretende ser, "história daquilo que é", a história-Dichtung, que Merleau-Ponty pretende herdar de Husserl, aos seus olhos não é censurável, de forma alguma, por exprimi-lo como filósofo, mas antes por não exprimi-lo "completamente" (MERLEAUPONTY, 1964, p. 231). Assim, para Merleau-Ponty a distancia entre a história "objetiva" e a história "vertical", se traduz no abismo existente entre "uma" filosofia (certamente, não "clássica") e "a" filosofia.

Mas se a doutrina da "linguagem indireta" é condição necessária para se compreender o que Merleau-Ponty entende por uma obra clássica, ela não é, de forma alguma, a sua condição suficiente. Afinal, a obra clássica não é apenas aquela que, antes de conter ideias, contém matrizes de ideias. Muito mais do que isso, é essencial a essa descrição do autor clássico a tese de que nós nunca terminaremos de desdobrar o sentido de sua obra. Se o "grande livro" é tão singular e inesgotável quanto a coisa vista, esta postulação de uma interpretação infinita não se calca, de forma alguma, em qualquer analogia, sempre remota, entre a visão e a leitura. Ela se 


\section{4}

funda, ao contrário, em uma certa filosofia da "produtividade", em que esta não se reporta, inteira, a qualquer cogito imperialista, uma filosofia que Merleau-Ponty só esboça, com as devidas barbas, em seu último período.

\section{III}

A recusa de um papel fundante ao cogito tácito que, no primeiro período da filosofia de Merleau-Ponty, detinha o privilégio de titular exclusivo daquela "produtividade" em que se originavam as criações humanas, sempre reportadas a uma intencionalidade da consciência, levará a uma revisão daquilo que era uma de suas mais evidentes consequências: a oposição abrupta e integral entre natureza e cultura. Uma vez recusada a "filosofia da consciência", será um mero corolário reconhecer que o "ponto de vista da criação, do Gebilde humano, - e o ponto de vista do 'natural' (do Lebenswelt como Natureza) são todos os dois abstratos e insuficientes" (MERLEAU-PONTY, 1964, pp. 227/28). E sabe-se que não se tratará apenas de neutralizar uma oposição, mas sim de estabelecer, entre as duas regiões, uma relação de "fundação". Doravante, o importante será "redescobrir" uma "Natureza-para-nós como solo de toda nossa cultura, e onde se enraíza em particular nossa atividade criadora, que, portanto, não é incondicionada..." (MERLEAU-PONTY, 1996, p. 44). A "reabilitação ontológica do sensível", que nos textos do período intermediário já marcava sua presença, mas apenas no plano das consequências, encontrará doravante as suas premissas, e enfim se saberá por que a "expressão propriamente dita, tal como a linguagem a obtém, retoma e amplifica uma outra expressão, que se desvela na 'arqueologia' do mundo percebido” (MERLEAU-PONTY, 1968, pp.12/13). Mas são algumas das condições a serem preenchidas para se legitimar esta "fundação" do logos proferido no logos silencioso do mundo sensível, que serão reveladoras de quem é, afinal, Merleau-Ponty leitor dos clássicos, ao menos em seu desenlace final.

Sabe-se que a primeira dessas condições será afastar a compreensão clássica e cartesiana da natureza como "produto". Se Descartes foi o primeiro a formular uma ideia de natureza que extrai as consequências da ideia de Deus, com ele este "mundo visível” se torna a única manifestação 
possível de uma produtividade infinita e, desde então, é no naturante que se refugia tudo o que podia ser interior à natureza, todo "sentido" é contrabandeado para Deus, a natureza perde todo e qualquer "interior", tornando-se apenas "a realização exterior de uma racionalidade que está em Deus” (MERLEAU-PONTY, 1995, p. 27). Se o naturado se torna mero "produto", ele é pura atualidade, sem potencialidades escondidas, ele está destituído de toda e qualquer "produtividade". Contra a compreensão cartesiana, trata-se agora de dar direito de cidadania a uma noção de natureza que se inspira em Schelling, uma natureza que não é apenas produto, não é "efeito morto", mas é também produtividade (MERLEAU-PONTY, 1995, p. 61). Se a natureza pensada como mero produto se deriva do infinito positivo, então será preciso reconhecer que "a filosofia só respira quando ela rejeita o pensamento do infinitamente infinito, para ver o mundo em sua estranheza” (MERLEAU-PONTY, 2000 , p. 370). Uma rejeição que, por si só, não é contudo qualquer garantia, visto que a concepção cartesiana de natureza pode muito bem sobreviver ao "complexo ontológico" que lhe deu origem. É o que ocorre com Sartre, censurado expressamente por Merleau-Ponty, visto que, no interior de sua ontologia, "o Ser é sem exigência, sem atividade, sem potencialidades” (MERLEAU-PONTY, 1995, p. 161). Uma censura que, na verdade, se estende facilmente à própria Fenomenologia da Percepção, já que ali a "natureza", tal como esta se apresentava na cena dirigida pelo Merleau-Ponty de então, também estava despojada de qualquer "atividade" ou "produtividade", sendo apenas um mero "correlato" "morto" da intencionalidade e do esquema corporal.

O beneficio que se espera deste namoro crepuscular com o romantismo? Agora se poderá reconhecer que a natureza tem "sentido", que ela é "autoprodução de um sentido", doravante ela tem um "interior", se determina "de dentro", ela não é mais "objeto", aquilo que está "diante" de nós, mas é antes o nosso "solo" (MERLEAU-PONTY, 1995, pp. 19/20) Neste novo cenário, a "natureza” finalmente poderá ser vista como um fundo ontológico, que se prolonga na arte ou na filosofia, em todo caso, na obra "válida" ou "bem sucedida". A natureza será compreendida como "uma produtividade originária que continua sob as criações artificiais do homem” (MERLEAU-PONTY, 1995, p. 169). Se o "mundo do silêncio", o "mundo percebido", é uma ordem em que há 
significações que são anteriores à linguagem, então toda criação humana é "chamada e engendrada pelo Lebenswelt", ela o prolonga e o testemunha (MERLEAU-PONTY, 1964, p.228). O logos da linguagem se apoia no logos do mundo natural, estético, e se há um logos do mundo sensível e um "espírito selvagem" que anima a linguagem, será preciso reconhecer que "a comunicação no invisível continua o que é instituído pela comunicação no visível, ela é seu outro lado” (MERLEAU-PONTY, 1995, p. 290). Mas para que se possa efetivamente afirmar que o logos silencioso "chama" o logos proferido", será preciso afirmar que o Ser é "infinito". Não o infinito positivo, que é "objeto", mas o infinito do Lebenswelt, que sendo infinito de Offenheit, é negativo, é aquele que efetivamente nos "ultrapassa", e pode dar conta da "profundidade do ser", de um "fundo inesgotável do ser” (MERLEAU-PONTY, 1964, p.223). É graças a essa postulação de um infinito que se encontrará a condição suficiente para poder afirmar que o "mundo perceptivo é no fundo o Ser no sentido de Heidegger", que, "apreendido pela filosofia em sua universalidade, aparece como contendo tudo aquilo que algum dia será dito" (MERLEAU-PONTY, 1964, pp. 223/224).

Assim, se a obra "clássica" é aquela que contém, mais que ideias, matrizes de ideias cujo "sentido" nunca terminaremos de desdobrar, se ela é passível de um comentário infinito, é porque, enquanto criação artificial do homem, ela "continua" uma produtividade originária que é “inesgotável”. Se a "natureza” é "o que há de mais velho", ela também “é algo de sempre novo" (MERLEAU-PONTY, 1995, p. 169). Se a obra clássica pode ser comentada ao infinito, é porque o Lebenswelt que ela prolonga e exprime já tinha a faculdade da eterna novidade. Era Nietzsche quem observava que uma das maneiras de se preservar o cristianismo, quando este já perdeu a sua forma dogmática, é impor ao mundo a faculdade da eterna novidade. Merleau-Ponty pode muito bem proclamar-se um "ateu” (MERLEAU-PONTY, 2000, p.369). Mas qual o alcance real dessa confissão? Afinal, o cristianismo pode muito bem sobreviver à morte do Deus dos clássicos. Assim, se o mundo não é mais Deus, o novíssimo "ateu" desejará sempre supor que este mundo "deve, no entanto, ser apto à divina força criadora, à infinita força de transmutação... É sempre ainda a velha maneira religiosa de pensar e desejar, uma espécie de aspiração a acreditar que, em alguma coisa, o mundo é igual ao velho, 
querido, infinito deus ilimitadamente criador - que em alguma coisa 'o velho deus vive ainda"” (NIETZSCHE, 1983, p. 395). Afinal, pode-se muito bem criticar o "infinito positivo", e substituí-lo por um infinito negativo. Mas o resultado que se espera desta operação visa, na verdade, garantir ao mundo o seu "fundo inesgotável de ser", a sua faculdade da eterna novidade. Assim, Merleau-Ponty pode galhardamente afirmar que, para ele, "a filosofia consiste em dar um outro nome" a isto que, por muito tempo, foi cristalizado sob o "nome de Deus" (MERLEAUPONTY, 2000, p. 371). Mas resta saber para onde aponta esta nova cerimônia de batismo, quando ela gira em torno destes "nomes", quase sinônimos entre si, que são "Ser bruto", "mundo percebido", "mundoda- vida" ou "natureza-para-nós".

Merleau-Ponty teria feito uma crítica, efetivamente radical, da "filosofia da consciência"? Os textos sugerem, enfaticamente, que não. A recusa da consciência individual não é uma recusa da consciência em geral, e aquele "Ser" que, doravante, estará no centro da suposta nova cena, como o "englobante", não sendo qualquer consciência "individual" terá, contudo, todos os traços de uma "consciência", só que, agora, universal ou cósmica. Afinal, por que tanta insistência em diferenciar a "natureza" da "simples coisa"? Porque, ao contrário da "simples coisa", esta natureza tem um "interior", ela é "autoprodução de um sentido", tem uma "produtividade" ou "atividade". Atributos que são típicos de uma "consciência”. E se Whitehead compreendia a natureza como "uma espécie de atividade", que se exerce "sem ser comparável à atividade de uma consciência ou de um espírito", aqui, o pronome deve ser claramente sublinhado, e a exclusão do modelo da consciência individual não proibirá, de forma alguma, que se fale em uma "subjetividade da natureza" (MERLEAU-PONTY, 1995, p. 161). E quando MerleauPonty for procurar um conceito "válido" de natureza, será para apontar a necessidade de se encontrar "algo" "na juntura do Ser e do nada", visto que a natureza sempre será este "subjetivo-objetivo" (MERLEAUPONTY, 1995, p. 102).

Da mesma maneira, Merleau-Ponty pode muito bem censurar a análise husserliana por estar "bloqueada" pelo quadro dos atos que a "filosofia da consciência" lhe impõe. Mas o que, ao fim e ao cabo, se propõe no lugar disso? Simplesmente, se dirá que é preciso "retomar e 


\section{8}

desenvolver a intencionalidade Fungierende ou latente, que é a intencionalidade interior ao ser" (MERLEAU-PONTY, 1964, pp.297/8). Mas se existe uma intencionalidade "interior ao ser", este "ser" será, necessariamente, uma espécie de "consciência”. Além do mais, sabe-se que falar em "intencionalidade", é ipso facto, falar em "teleologia”. E será justamente esta "teleologia" que estará no centro da cena de Merleau-Ponty, no final de seu ensaio sobre "O filósofo e sua sombra". A “teleologia” será apresentada, ali, como sendo o verdadeiro "irrelativo", aquilo que é "juntura e membrura do Ser, que se consuma através do homem” (MERLEAUPONTY, 1960, p.228). Se este Ser é habitado por intencionalidade e, logo, por teleologia, ele é pensado segundo o modelo de uma consciência e, por isso, Merleau-Ponty se deixava seduzir, espontaneamente, por uma linguagem singelamente antropomórfica, ao descrever a passagem do "sentido perceptivo" ao "sentido linguístico": ele dizia que a linguagem realiza, rompendo o "silêncio", aquilo mesmo que o silêncio "queria", mas não "obtinha” (MERLEAU-PONTY, 1964, p. 230). Assim, se esta teleologia se consuma apenas através da "criação" humana, então este "homem" será, por princípio, um personagem central e essencial à Offenbarung do novo "absoluto". Uma vez criticado e afastado o "humanismo", como pedem os sons dos novos tempos, resta que o "lugar do rei" será ocupado, doravante, por um evidente "antropocentrismo" que, por mais estilizado e etéreo que seja, não deixa de ser, apenas, um bastante ortodoxo antropocentrismo cristão.

E se é assim, que nós compartilhemos, com Merleau-Ponty, o seu "prazer do texto". Colaboremos, portanto, mesmo com nossa ínfima parte e força, nesta tarefa "infinita" que é a leitura e interpretação dos "clássicos", sempre tão "inesgotáveis" quanto a coisa percebida. Mas, ao menos, façamos isso sabendo que, neste precioso momento, estaremos sendo, todos, na cerimônia de reconhecimento de cada sentido "inédito", os novos "crentes" de um ideário que, sem sombra de dúvida, é genuinamente cristão. Afinal, os textos de Merleau-Ponty indicam, suficientemente, que, no derradeiro ato de sua vida como filósofo, este antigo colaborador da revista Esprit permaneceu, integral e religiosamente, fiel à sua arcaica origem. 


\section{Referências bibliográficas}

MERLEAU-PONTY, M. 1945. Phénoménologie de la perception. Paris:

Gallimard.

MERLEAU-PONTY, M. 1960. Signes. Paris: Gallimard.

MERLEAU-PONTY, M. 1964. Le Visible et l'Invisible. Paris: Gallimard.

MERLEAU-PONTY, M. 1966. Sens et non-sens. Paris: Nagel.

MERLEAU-PONTY, M. 1968. Résumés de cours. Paris:Gallimard.

MERLEAU-PONTY, M. 1969. La Prose du Monde. Paris: Gallimard.

MERLEAU-PONTY, M. 1989. Éloge de la Philosophie. Paris: Gallimard, Folio

MERLEAU-PONTY, M. 1995. La Nature. Paris: Seuil.

MERLEAU-PONTY, M. 1996. Notes de cours. Paris: Gallimard.

MERLEAU-PONTY, M. 2000. Parcours II. Lagrasse:Verdier.

MERLEAU-PONTY, M. 2002. Causeries. Paris: Seuil.

MERLEAU-PONTY, M. 2003. L'Institution. La Passivité. Paris: Belin.

NIETZSCHE, Fr. 1983. Obras incompletas. São Paulo: Abril Cultural.

SARTRE, J-P. 1989. Que é a literatura? São Paulo: Ática. 